\title{
RADOŠUMS, RAŽOŠANA UN TIESĪBU ZINĀTNE
}

\section{CREATIVITY, PRODUCTION AND LEGAL SCIENCE}

\author{
Diāna Apse, Dr. iur. \\ Latvijas Universitātes Juridiskās fakultātes \\ Tiesību teorijas un vēstures zinātṇu katedras docente
}

\begin{abstract}
Summary
The purpose of this article is to analyse and to consider the most important aspects of creative jurisprudence, which are important for a common legal order in the era characterised by the birth of new systems and ideas. Attempts were made to find answers to the following questions: whether the conditions of the pandemic and the technocratisation of all fields have a significant impact on lawyers, law students, law education/academics from the point of view of the concepts of production and creativity. It has been found that specific doctrinal insights are becoming increasingly important in the clarification and application of existing and newly created rights, which is a valuable argument in the drafting of a legal act. This article is predominantly relevant from a theoretical point of view.
\end{abstract}

Atslēgvārdi: vērtības, tiesiskā sistēma, tiesību zinātne, radošums.

Keywords: values, legal arrangement, legal science, creativity.

\section{Ievads}

Raksta mērḳis ir aplūkot un analizēt svarīgākos radošas tiesību zinātnes aspektus, kas ir nozīmīgi kopīgai tiesiskai kārtībai jaunu sistēmu un ideju piedzimšanas laikmetā. Mēgināâts rast atbildes: vai pandēmijas apstākḷi, visu jomu tehnokratizācija būtiski ietekmē tiesībnieku, jurisprudences studentu darbību, tiesību zinātni, raugoties no ražošanas un radošuma jēdzienu platformas. Tiesnešu īpašās doktrīnas atziṇas kḷūst arvien nozīmīgākas pastāvošo un jaunradāmo tiesību noskaidrošanā un piemērošanā, - tas ir vērtīgs arguments tiesību akta tapšanā laikā, kad likumdošana ir dominējošais pārvaldības instruments. Raksts varētu būt vairāk noderīgs teorētiskā aspektā.

\section{Ražošana un pandēmijas krīze}

Pienācis pandēmijas un ciparu kazuistikas laikmets, kuru raksturo atslēgvārdi: burbulis, nomāktība, akadēmiskais nogurums, izdegšana, digitālās prasmes, to praktizēšana, jēgpilni ierobežojumi, drošības standarti izglītībā u. c.

Kā tādos apstākḷos neražojot, bet radoši nonākt līdz sabiedrībai kalpojošām tiesību zinātnes atziṇām? 
Vieniem pasaule kḷuvusi lēnāka, atklājas, ka arī radošais pienesums palēninājies. Valda zināms garīgs izsalkums, tāpēc jo svarīgāk ir ieraudzīt un izprast patieso lietu būtību, arī krīzes ierobežotās tiesībās.

Pilnīgas taisnības pasaulē nebūtu vajadzības pēc tiesību zinātnes. Tās neaizstājamais mūžīgums liecina pats par sevi.

Ražošanai piemìt skaițu valoda, ciparu daba. To raksturo devums kopproduktā, darba ražīgums, ko panāk, darbiniekus aizstājot ar moderniem ražošanas līdzekḷiem. Viens no tās attīstībai nozīmīgiem un pastāvīgi risināmiem jautājumiem - kā palielināt konkurētspēju. İpaši aktuāls tas ir krīzes apstākḷlos. Taču atbilde uz to ir vienkārša un logiska - palielinot finansējumu apmācībām, pētījumiem un izstrādnēm.

Ražošanai ir cieša saikne ar ražotspēju. Tā pieprasa kvantitāti. Ražotspēja ir maksimālais daudzums, ko var saražot, ja visus tautsaimniecības, atsevišķās nozares vai firmas resursus izmanto iespējami pilnīgi. Investīciju trūkums vai ražotprasmes nepietiekamība var izraisìt ražotspējas ierobežotību, bet pieprasījuma trūkums - nepietiekamu ražotspējas izmantošanu. ${ }^{1}$ Skan sausi. Ražīguma līmenim esot zemākam, var sasniegt augstāku ražīguma pieauguma tempu. ${ }^{2}$

Vai tiesību zinātnē iespējams kvalitatīvs lēciens arī krīzēe Izglītības sfēra un zinātnes lauks ir tik darbietilpīgi. Ja ražošana ir attiecināma arī uz tiesību zinātni, tad ir jārod iespējas un resursi iespējām izlīdzināt krīzes ciklus arī tai! Bet tiesību zinātnei izsenis nav bijis pienācīga atbalsta! Nākotne nepastāv bez tagadnes un pagātnes!

"Mēs nevaram pie katrām ekonomiskām grūtībām mainìt politisko režìmu un spēlēties ar Satversmi - ekonomiskā stabilitāte - demokrātija, un katrs dara ko grib, ekonomiskā krīze - autoritārisms, un viens atbild par visiem..”

Profesore Ineta Ziemele uzsvērusi, ka savā ziṇā pašreizējā krīze ir uzskatāma par unikālu, arī nāk par labu, jo parāda, kā ir par daudz, kas ir par smagu un kas nav vajadzīgs. ${ }^{4}$

Profesore Sanita Osipova savulaik rakstīja, ka krīze būs pārvarēta tad, kad tauta šo faktu būs pamanījusi, kad cilvēki jutīsies droši savā zemē un, lai sarūpētu iztiku sev un gímenei, viṇiem nebūs jāpamet dzimtene. ${ }^{5}$ Laikā, kad vieni zaudējuši motivāciju un bieži arī finansiālās iespējas vispār nodarboties ar ko radošu, atsvešinājušies, noslēgušies, citi nopietni ķērušies pie iegūtā laika, veltot to pārdomām par vērtībām.

Kā klājas mums - tiesībniekiem, mācībspēkiem?

Andra Akmentiṇa grāmatā "Meklējot Ezeriṇu” lasāms: "Kamēr sakleḳerē kroņa papīrus, kamēr izšķir, kas labs, kas ḷoti labs, kas īsti labs, tumsa klāt. Kā gribētos rakstīt ne tikai burta dẹl̦! Lasīt sev un iegremdēties cita rakstītajā vārdā [..]”6

\footnotetext{
${ }^{1}$ Ideju vārdnīca. Domātāji, teorijas un jēdzieni filozofijā, zinātnē, reliğijā, politikā, vēsturē un mākslā. Rīga: Zvaigzne ABC, 1999, 450. lpp.

2 Turpat, 450. lpp.

3 Osipova S. Vadonisma atdzimšana Latvijā. Grām.: Osipova S. Nācija, valoda, tiesiska valsts: ceḷā uz rītdienu. Rīga: Tiesu namu aǵentūra, 2020, 122. lpp.

4 Ziemele I. Krīzes mācības un prognozes. Pieejams: https://www.delfi.lv/delfi-tv-ar-jani-domburu/ pilnie-raidijumi/delfi-tv-ar-jani-domburu-atbild-ziemele-kazaks-un-zagars-macibas-2020-prognozes2021-pilns-ieraksts.d?id=52796017 [aplūkots 23.02.2021.].

5 Osipova S. 2020, 119. lpp.

${ }^{6}$ Akmentiņš A. Meklējot Ezeriṇu. Jānis Ezeriņš. Rīga: Dienas Grāmata, 2021, 52. lpp.
} 
Arī šajā dīvainajā laikā tiesībnieki neatrodas intelektuālā trimdā un nav atrauti no iedvesmojošiem piemēriem spožāko starpkaru tiesību zinātnieku (Augusta Lēbera, Roberta Akmentiṇa, Vasilija Sinaiska u. c.) un mūsdienu Latvijas vai starptautisko tiesību zinātnieku darbu atziṇām. Tiesību zinātnē ir iespējama tradīciju, simbolu, tiesiskās domas pārnese un turpināšana. Tikai jāṇem vērā pandēmijas laika ierobežojumu īpatnības.

Šobrīd zināmas ierobežotas pārvietošanās brīvības apstākḷıs svarīgi ir nezaudēt tiesību un taisnīguma trūkuma izjūtas, t. i., garīgi nepamest savu dzimteni. Lai arī teju katrs trešais Latvijas iedzìvotājs piel̦auj nelielu politisko brīvību ierobežošanu, lai panāktu ekonomiskā stāvokḷa uzlabošanu, kā liecina pētījumu centra SKDS veiktās aptaujas dati ${ }^{7}$, ipaši nozīmīgs ir šādu ierobežojumu pamatojums un izskaidrošanas darbs.

Mācībspēki ir cieši saistīti ar saviem studentiem (tiešsaistēe, sarakstē), un redzam, ka daudzus nodarbina jautājumi: vai mēs vēl esam vajadzīgi cits citam? Tiešsaiste liek piedalìties, bet vai tā liek patiesi piedzīvot notikumu? Arvien motivējošāki un nozīmīgāki kḷūst pedagoǵiskie, cilvēciskie un citi sociāli aspekti studiju procesā, kur digitālie risinājumi ir viens no saskaitāmajiem studenta iespējami labāku studiju ieguvumu, zināšanu, profesionālo un sociālo prasmju attīstībā.

Iespējams, ka daudziem distance samazina radošuma izpausmes, atņem laiku, izstumj personību, aizvietojot to ar "pogu eksperta” tehniskumu. Zūd privātās dzīves laika robežas. Pastāv riski, ka studentu rakstīšanas vēlme un prasme regresē, degradējas argumentācijas māksla. Lasīšana daudziem steidzīgajā pasaulē šķiet kā lieks laika tēriņš, nevis mentāli harmonizējošs instruments apzinātības un kultūras dziḷākai izpratnei.

Runājot ar studentiem, jāpiekrīt pētījuma "Latvijas pusaudžu un jauniešu mentālā veselība Covid-19 pandēmijas ietekmē" secinājumiem, kas liecina, ka daudzu jauniešu mentālā veselība ir pasliktinājusies un daudziem tā ir kritiskā lìmenī. ${ }^{8}$

Rodas šaubas, vai dzīve ciparu pasaulē nenogalinās jaunās paaudzes intuīciju, tēlaino domāšanu, simbolu veida domāšanu? Vai algoritmu laikmetā cilvēka prāts un garīgā pasaule netiks aprobežoti, aizvietoti ar surogātiem, ietekmējot tiesiskās kultūras līmeni un demokrātijas izpratni.

Tiesiskums un demokrātija labi darbojas tikai sabiedrībās ar augstu pilsoniskās apzinātības līmeni un tiesisko kultūru, kas cita starpā ietver arī izglītotību un zināšanas par valsts, tai skaitā tiesas, uzbūves un darbības principiem. Uz faktiem

\footnotetext{
${ }^{7}$ SKDS pētījums. Pieejams: https://www.apollo.lv/7186430/skds-teju-tresdala-iedzivotaju-pielauj-politisko-brivibu-ierobezosanu-ekonomiska-stavokla-uzlabosanai [aplūkots 20.02.2021.].

8 "Režìma un laika struktūras būtiskas izmaiṇas nelabvēlīgi ietekmē mentālo veselíbu, īpaši jauniešu vidū. Tiešsaistes sarunās ir būtisks trūkums. Nav iespējams acu kontakts (kamera augstāk nekā ekrāns). Līdz ar to smadzenes reaǵē atškirīigi. Klātienes sarunās noteiktu smadzeṇu regionu reakcijas ir spilgtāk izteiktas. Iztrūkst "kā dzirdam", attēla un skaņas nobīde laikā traucē uztvert informāciju, visvairāk jauniešus mulsina tas, ka daudzu teiktais nāk no viena avota. Līdz ar to lielāks nogurums. Pietrūkst ķermeņa valodas, zīmīgu žestu, iztrūkst sinhronizēšanās iespēja labākai tēmas izpratnei, "kā es izskatos ekrānā" daudziem liek izslēgt kameru. 63\% Latvijas jauniešu atzīst: viṇu mentālā veselība ir pasliktinājusies pandēmijas laikā, 72\% pēdējo divu nedēḷu laikā ir saskārušies ar psiholog̣iskās veselības problēmām, nomāktību, ātru aizkaitināmību, bezmiegu, panikas lēkmēm, zūd motivācija mācīties u. c." Sk.: Latvijas pusaudžu un jauniešu mentālā veselība Covid-19 pandēmijas ietekmē. Pētijums. Pieejams: https://61d65e37-01a0-426e-b0f4fd3a092c2742.filesusr.com/ugd/9c12e9_f48f2b1239914bb7b85b88a2d14df51f.pdf [aplūkots 20.02.2021.].
} 
un pierādījumiem nebalstīti, tikai emocijās sakṇojušies apgalvojumi neliecina par šādu augstu apzinātību un kultūru un tikai grauj valsts un sabiedrības pamatus. ${ }^{9}$

Šis pārbaudijumu gads ievelk ražošanā un ietekmē radošumu un tiesību zinātni tā, ka laikietilpīgam pētījumam var neatlikt laika.

\section{Radošums}

Radošums liek veidot piesardzīgas attiecības ar ražošanu. Radošumā īpaši nozīmīgi ir laiks un personība. Laiks atklāj un izvētī personību atstātos nospiedumus vēsturē, kultūrā, tiesību laukā.

Pieredzam ekstrēmu laiku, kad stihiski svārstās filozofiju, politiku, mākslas, mūzikas pasaules iedibinājumi, izsalkuši ir kultūras mīḷtōāi.

Radoši tiesību laukā tiek radītas vērtības, kas saistītas ar sabiedrības izdzìvošanu. Tām ir augsta cena. Tas liek domāt! Domāt par to: vai vara jāsadala atbilstoši varas dališanai vai visiem vienādi? Vai pienācis romiešu tiesību principu gals? Kāda ir tiesību avotu mijiedarbība mūsdienās? Vai tiesiskā kārtība var atbilst katra indivīda pārliecībai? Kā ar cilvēka cieṇu? Pilnīgas brīvības sasniegšanas iespējas mūsdienās, brīvības morāle ierobežojumu laikā, tiesību un vērtību attiecības.

Vērtības ir tiesību pamats, to îstenošana un aizsardzība - tiesību mērksis. ${ }^{10}$ Ja vērtības ir kā orientieri, kas nodrošina sabiedrības ilgtspēju, to vienojot, tad tiesības jāîsteno tā, lai sabiedrības vērtības tiktu aizsargātas vislabākajā veidā, lai vairotu personu uzticēšanos valstij un tiesībām.

Veltīt laiku un saprast, ka darītais tevi neapmierina, - tuvāk ražošanai. Tad, kad tas tiek konstatēts un tiek pārvarēts, esam koncentrējušies, pacietīgi, nonākam tuvāk radošumam. Radošumam vajag laiktelpu!

Tikai tad attīstās vērīgums, talants, augḷ nes ieguldītais darbs un neatlaidība, kas padara ikvienu mūsu nodarbi par radošu un jēgpilnu. Cilvēka vienreizība un gars nosaka radošuma mērogu, jo brīvības saglabāšana ir ikviena atbildība sadarbībā.

Līdztekus sociālajai kopības izpratnei pastāv otra kulturāla forma. Tā attiecas uz tādiem kopīgiem, taču ne obligāti kopīgiem elementiem kā valoda, literatūra, mūzika, māksla un arhitektūra. Kas uzṇemas atbildību par nākamajām paaudzēm, tas apietas taupīgi ar frāzēm "kultūras nācija” vai "dzejnieku un domātāju tauta”. Taču pašu lietu viņš uztver nopietni, ir angažēts paša sabiedrībā un sniedz savu artavu, lai nākamajām paaudzēm atstātu vismaz tikpat lielu valodas un kultūras kapitālu, kādu to pats ir mantojis. ${ }^{11}$

Valoda kā līdzeklis cīnai ar haosu nevar ne tikai bez mākslas, dzejas, mūzikas, bet arī bez tiesību zinātnes, kur svarīgas ir fonētiski atšķirīgās pazīmes. Domājam ar vārdu tēliem. Taču ciparu laikmetā valodas struktūra var iet bojā. Tāpēc jo svarīgāk saglabāt un izkopt juridisko valodu.

Novērotājs pats ar savu vērtību izpratni ietekmē pētnieciskās pieejas procesu un nevar iegūt neatkarīgu realitātes ainu, līdz ar to zinātniskā atziṇa nav iespējami

9 Tieslietu padomes rezolūcija par tiesas un tiesneša kritikas jautājumiem. Pieejams: https://lvportals.lv/ dienaskartiba/324388-tieslietu-padomes-rezolucija-par-tiesas-un-tiesnesa-kritikas-jautajumiem-2021 [aplūkots19.02.2021.].

10 Grigore-Bāra E. Pienākums teikt patiesību primāri būtu jāsaprot kā aizliegums melot. Jurista Vārds, 04.08.2015., Nr. 30 (882), 29. lpp.

11 Hefe O. Taisnīgums. Filosofisks ievads. Rīga: Zvaigzne ABC, 2009, 120. lpp. 
objektīva. Vajadzīga vēl arī kritika un polemika, pieejamība un pārbaude laikā. Tad to var uzskatìt par tiesību zinātnes atziņu kā tiesību palīgavotu, kas pieškirir tiesībām jēgu.

\section{Tiesību zinātnes aktualitātes}

Zinātne ir viss, kas apstiprinājies līdz tādai pakāpei, ka nebūtu saprātīgi vismaz pagaidām tam nepiekrist. ${ }^{12}$

Latvijas Zinātṇu akadēmijas prezidents Ivars Kalviņš uzsvēris: Latvijas zinātne ilgstoši ir badināta, tāpat kā augstākā izglìtîba. Lìdz ar to mums ir grūti konkurēt ar to valstu zinātniekiem, kur investîcijas pētniecībā un inovācijās ir stipri augstākā lìmenī. Bet tas nenozìmē, ka Latvijā nav augstas raudzes pētniecỉbas. ${ }^{13}$ Vēl jo vairāk tas attiecināms uz tiesỉbu zinātni.

Līdz labi formulētai tiesību zinātnes atziņai vai grāmatai jānonāk caur radošuma mokām, šaubām un paškritikai. Zināšanas ir uzskatu aizstājējas un atziṇu briedinātājas. Lai pareizi izmantotu zinātnisku atziṇu, nozīmīga ir juridiskās izglītības kvalitāte un zinātniski pētnieciskās intereses atmodināšana studentos.

Daudziem šì interese mostas vēl pirms jurisprudences studiju uzsākšanas.

Kādi tiesību jautājumi interesē un nodarbina Latvijas nākotni, pēdējo klašu skolēnu prātus? Rīgas regiionālā konference pulcē jaunos pētniekus, kuri prezentēja savus pētijumus šã gada martā. Viṇi pētijuši gan uzvārdu maiņas tiesisko bāzi un tendences Latvijā dažādos laika posmos, gan bērnu biometrisko datu identificēšanas un publiskošanas juridiskās sekas, gan skolēnu pašpārvaldes pamatdokumenta izveides nepieciešamību kādā Rīgas vidusskolā, gan jauno psihoaktīvo vielu aprites regulējuma un dekriminalizācijas jautājumus Latvijā, gan trauksmes celšanas likuma tiesiskā regulējuma problemātiku, gan arī sporta manipulāciju krimināltiesisko regulējumu Latvijā.

Bakalauru studiju posmā pētnieciskā interese LU Tiesību teorijas un vēstures katedrā saistīta ar vispārējo tiesību principu satura atklāšanu, tiesību avotu piemērošanas jautājumiem, tiesnešu pienākuma respektēt nevainīguma prezumpciju krimināllietas iztiesāšanā un saziṇā ar masu medijiem, tiesnešu ētikas prasību komunikācijai tiesas procesā, konstitucionālās kontroles kompetences izskatît Satversmes rakstīto tiesību normu atbilstību nerakstìtajām tiesību normām izpēti u. c.

Mağistrantūras studenti aizstāvējuši interesantus pētījumus par bijušās Valsts drošỉbas komitejas dokumentu izmantošanas un publiskošanas tiesiskumu Latvijā, par sociālo nodrošinājumu jūrniekiem Latvijā u. c.

Vairāki bakalauru un mağistru darbu izstrādātāji jūt nepieciešamību pētīt surogācijas legalizācijas aspektus, arī Eiropas cilvēktiesību prakses ietekmes uz Latvijas tiesību politiku, jo Eiropas Cilvēktiesību tiesas spriedumi virknē valstu ir izraisijuši noteiktu rezonansi un ir bijušas tādas vai citas tiesibpolitiskās diskusijas par tiem, veidojot valstu nostājas un formulējot viedokli par surogāciju.

12 Gūlds S. Dž. Atziṇa no lekcijas par evolūciju. Grām.: Ideju vārdnīca. Domātāii, teorijas un jēdzieni filozofijā, zinātnē, relig̣ijā, politikā, vēsturē un mākslā. Rīga: Zvaigzne ABC, 1999, 572. lpp.

13 Landorfa S. Cik tālu ir Bībele no zinātnes? Saruna ar Ivaru Kalviņu. Pieejams: https://jauns.lv/raksts/ sievietem/429067-cik-talu-bibele-ir-no-zinatnes-saruna-ar-ivaru-kalvinu [aplūkots 22.02.2021.]. 
"Varenais septinnnieks" - pandēmijas laika doktora grāda ieguvēji - 2020. gadā aizstāvēja savus darbus sēdēs tiešsaistes platformā. Juris Rudevskis ar darbu "Subsidiaritātes princips Eiropas cilvēktiesību tiesas judikatūrā", ${ }^{14}$ Jānis Priekulis ar darbu "Efektīvs tiesību aizsardzības līdzeklis pret likumu", ${ }^{15}$ Arta Snipe ar darbu "Zemes piespiedu noma Latvijas Republikas pilsētās, ja uz zemes atrodas privatizēta daudzdzīvokḷu dzīvojamā māja", ${ }^{16}$ Evija Novicāne ar darbu "Valdes locekḷa atbildība par kapitālsabiedrībai nodarītajiem zaudējumiem", ${ }^{17}$ Lolita Buka ar darbu "Tiesību tikt aizmirstam interneta meklētājprogrammās mijiedarbība ar izteiksmes brīvību", ${ }^{18}$ Nērika Lizinska ar darbu "Valsts kā starptautiska škīiejjtiesas līguma puse", ${ }^{19}$ Aleksandrs Potaičuks ar darbu "Pārrobežu administratīvais akts Latvijā un Eiropas Savienībā". ${ }^{20}$

İpaši vēlos izcelt Jura Rudevska pētijuma pienesumu. Darbā tiek secīgi aplūkoti trīs subsidiaritātes principa aspekti - vispārfilozofiskais, materiāltiesiskais un procesuālais - un analizēta katra šì aspekta darbỉba ECT judikatūrā.

Juris Rudevskis uzteicamajā metodologiskajā pieejā izvēlējies klasisko spriešanas un pierādīšanas ceḷu: aristoteliskās log̣ikas ievērošanu, spriešanu Aristoteḷa kategorijās, atbildes meklēšanu senāku laiku autoritāšu darbos, strīdīgos jautājumus aplūkojis strīdīgās sholastikas formā: tēze - sagaidāmais iebildums, iebilduma atspēkojums. Šajā ietvarā lietotas filologiskā, vēsturiskā, salīdzinošā un juridiskās prognozēšanas metode (iespējamā prognozēšana, kā situācija attīstīsies nākotnē, un labākie iespējamie risinājumi). ${ }^{21}$

Profesores, Satversmes tiesas priekšsēdētājas Sanitas Osipovas grāmata "Nācija, valoda, tiesiska valsts: ceḷā uz rītdienu" - fundamentāls darbs juridiskās izglìtības un tiesību zinātnes attīstībai tiesiskā un brīvā sabiedrībā - atvēršanas svētkus piedzīvoja vasarā. Rakstu krājums uzskatāms par tiesiskuma kultūras, tiesību vēstures kā kvalitatīvas jurisprudences pamata un tiesību zinātnes un prakses kā nākotnes jurisprudences kvalitatīvas konstrukcijas saiknu apskats.

Būtisks pienesums tiesību zinātnē ir februārī publicētā grāmata par tiesību sistēmu Eiropas Savienības valstīs, kurā 17. sadalıu par Latvijas tiesību sistēmu veidojusi profesore, Satversmes tiesas tiesnese Daiga Rezevska, kas akcentējusi dabisko tiesību skolas ievērojamo nozīmi tiesību avotu doktrīnas, pamatnormas, vispārējo tiesību principu izpratnē un ietekmē uz demokrātiju balstîtajā tiesiskajā kārtībā Latvijā. ${ }^{22}$ Tà vairākos līmeņos izpaužas tiesību zinātnes radošums pēdējā gada laikā.

\footnotetext{
14 Pieejams: https://dspace.lu.lv/dspace/handle/7/52394 [aplūkots 10.02.2021.].

$15 \mathrm{https} / /$ dspace.lu.lv/dspace/handle/7/52869 [aplūkots 10.02.2021.].

16 Pieejams: https://dspace.lu.lv/dspace/handle/7/52943 [aplūkots 10.02.2021.].

17 Pieejams: https://dspace.lu.lv/dspace/handle/7/53276 [aplūkots 10.02.2021.].

18 Pieejams: https://dspace.lu.lv/dspace/handle/7/53366 [aplūkots 10.02.2021.].

19 Pieejams: http://5.179.1.228/dspace/handle/7/53367 [aplūkots 10.02.2021.].

20 Pieejams: https://dspace.lu.lv/dspace/handle/7/53370 [aplūkots 10.02.2021.].

21 Sk. plašāk darba 20. lpp.: https://dspace.lu.lv/dspace/bitstream/handle/7/52394/298-77154-Rudevskis_Juris_TieZB95010.pdf?sequence $=1$ \&isAllowed $=y$ [aplūkots 10.02.2021.].

22 Plašāk sk.: Legislation in Europe. A Country by Country Guide. Ulrich Karpen and Helen Xanthaki (eds.). Pieejams: https://www.bloomsburyprofessional.com?uk?legislation-in-europe-9781509924707/ [aplūkots 12. 02.2021.].
} 


\section{4. İpašã doktrīna}

Tiesību filozofs Otfrīds Hefe, brīdinot par tiesnešu valsts riskiem, uzsvēris: "Kur mazinās eksekutīiā un legislatīvā vara, tur pastiprinās judikatīvā vara [..] Jo īpaši darba tiesībās justīcija ir kḷuvusi par aizstājošo likumdevēju [..] Pat tur, kur tiesai ir tiesības izškirties par likumu atbilstību satversmei, tai ir jāpakḷaujas "pašierobežošanās ètosam" [..] Neviena satversmes tiesa nedrīkst attīstīt tādu ekspansīvu pašizpratni, kas pat nedaudz līdzinātos Platona filosofu kundzības, tiesnešu kundzības variantam. Tā vietā tai jāatceras satversmes tiesas sākotnējā intence - krasas netaisnības atvairīšana." 23

Gan tiesas, gan likumdevējs to pārdomā un pārdomās, pieņemot izšḳirīgus lēmumus tiesiskās sistēmas pilnveides jautājumos, ṇemot vērā Satversmes tiesas nolēmumus.

Lìdz ar to tieši tiesneša atsevišķais viedoklis dažos jautājumos kḷūst īpaši nozīmīgs, norādot uz iespējamiem risinājumiem saistībā ar argumentiem vairākuma spriedumā.

Satversmes tiesas 2020. gada 12. novembra spriedums lietā Nr. 2019-33-01 "Par Darba likuma 155. panta pirmās daḷas atbilstību Latvijas Republikas Satversmes 110. panta pirmajam teikumam"24 tiesiskajā sistēmā iezīmē nopietnu pagriezienu, kuram tiesībpolitikā ir indikācijas un kontrindikācijas. Tāpēc likumdevējam tas jāvērtē analītiski, rūpīgi un sistēmiskā kopsakarā ar atsevišķajām domām, kuras pie sprieduma pauduši tiesneši Sanita Osipova ${ }^{25}$ un Aldis Laviṇš ${ }^{26}$ (domājot arī par iespējami paplašināti tulkotās normas mērḳii).

Taču par ikvienu svarīgu un nozīmīgu valsts vai sabiedrības dzīves jautājumu reglamentāciju, kuros nepieciešama konceptuāla izšķiršanās un politiska diskusija, jālemj likumdevējam pašam. ${ }^{27}$

Jāṇem vērā, ka "ikviens likumdevējs realizē nevis savu varu, bet gan tautas varu. Tātad gan nacionālajām, gan pārnacionālajām saistošajām normām ir jātop tikai tam īpaši tautas legitimētās institūcijās, ievērojot pilnvarojuma robežas. Šîs pilnvarojuma robežas skaidri nosaka katras valsts konstitūcija"28.

Visi konstitucionālie orgāni ir cieši saistīti ar varas dalī̌̌anas un likumības principiem, lai realizētos taisnīgums, miers un sociālā stabilitāte. Tāpēc likumdevējam kā nākotnes rīcības un tiesiskā ietvara mērs kopsakarā jāṇem vērā sprieduma un tiesnešu mazākuma īpašās doktrīnas atziņas.

Vēsture rāda, ka krīzēs no opozicionāru vidus rodas pravieši. Vēstures virzība un jēga atklājas aristoteliskā tikumības mācībā un praviešu sociālā taisnīguma ideju (kur pirmā vieta ticībai un cilvēka ètiskajiem uzdevumiem) sintēzē, līdz izdodas pamanìt attīstības cikliskumā tik nepieciešamo vertikāli, vēstures ètisko mērḳi. ${ }^{29}$ No tā vēlāk attīstījusies Rietumu kristīgās civilizācijas atziṇa, ka cilvēks pats spēj lemt par savu dzìvi.

\footnotetext{
${ }^{23}$ Hefe O. Taisnīgums. Filosofisks ievads. Rīga: Zvaigzne ABC, 2009, 59. lpp.

${ }^{24}$ Latvijas Vēstnesis, 16.11.2020., Nr. 222.

${ }^{25}$ Latvijas Vēstnesis, 12.01.2021., Nr. 7.

26 Turpat.

27 Osipova S. 2020, 374. lpp.

28 Turpat, 369. lpp.

29 "Mūžīgais likums, ko griek̦i saskatīja matērijas harmoniskā attīstībā un kustībā, jūdiem īstenojās cilvēces vēstures pārvērtībās, apliecinot vēstures ētisko mērḳi.” Sk.: Dowson Ch. Progress and Religion. Garden City (New York), 1960, p. 125.
} 
Senāta praksē īpašā doktrīna izpaudusies Civillietu departamenta senatoru Intara Bistera, Andas Briedes un Mārītes Zāgeres atsevišķajās domās un senatoru vairākuma kritikā par risināmā tiesību jautājuma formulējumu: vai tiesas, kas izskatījusi lietu pēc būtības, spriedums stājas spēkā daḷā, ja atsevišḳi tās faktu juridiskie novērtējumi nav apstrīdēti apelācijas vai kasācijas kārtībā.

Vairākuma viedoklis tiek kritizēts arī par to, ka tas faktiski akceptējis, ka puse, kura nav pārsūdzējusi pirmās instances tiesas spriedumu, apelācijas instancē, skatot lietu no jauna, var panākt sev labvēlīgu iznākumu. Tātad, liekot tiesai vēlreiz vērtēt pilnīgi visus apstākḷus, senatoru vairākums, pretēji dispozitivitātes principam, pēc būtības attaisnojis atbildētājas bezdarbību savu tiesību izlietošanā, kas nebija piel̦aujams. ${ }^{30}$

Latvijas Republikas Senāta Civillietu departamenta 2020. gada 25. novembra spriedumā lietā Nr. SKC-41/202031, kas pieṇemts paplašinātā 11 senatoru sastāvā, citstarp izcelta tēze par puses pieaicināta tiesību zinātnieka atzinuma statusu, norādot, ka civilprocesā par strīda apstākḷu juridiskās kvalifikācijas jautājumiem atzinums nav atzīstams par tiesību palīgavotu, kā arī nav atzīstams par pierādījumu Civilprocesa likuma 92. panta izpratnē.

Attiecībā par iepriekš minēto jāpaskaidro, ka praktizēšana atbildētāja pārstāvja advokāta birojā izslēdz neitralitāti un liek apšaubīt objektivitāti. Šāda advokāta vai tiesībzinātnieka atzinumam nepiemìt tiesību palīgavota pazìmes, jo tas iesniegts pēc atbildētāja pasūtījuma, viṇa interesēs, nav publicēts un pieejams zinātniskajai polemikai.

Likumdošana ir vispopulārākais pārvaldības instruments Eiropā. Pandēmijas situācija pastiprinājusi izpildvaras tiesību aktu skaitu saistībā ar dažādiem ierobežojumiem. Ja vara nosaka ierobežojumus, ko būtiska sabiedrības daḷa neakceptē, ierobežojumiem nav lielas jēgas. Pandēmijas laikā amatpersonām ir grūtāk respektèt autoritatìvas un fundamentālas tiesību vērtības un tiesību zinātnes atziṇas par brīvību ierobežojumiem.

Brīvība, kas balstās uz bailēm no pilsoṇu sadursmēm, tāpat kā brīvība, kura balstās uz valdības neuzticamību, ir atkarīga no doktrīnas par kādu "ideālu" brīvību. Tā iepriekšēji pieņem šādu ideālas brīvības doktrīnu, jo tā mums nosaka, kad un kā panākt kompromisu, tāpat kā valdības neuzticamība tiek mērīta ar tās nespēju sasniegt “ideāla” doktrīnas noteiktos mērḳus. Turklāt šīs doktrīnas par brīvību, kas saistīta ar nepieciešamībām un kompromisiem, noved mūs pie "nepilnīgas brīvības" - brīvības no valdības rīcības, un visbiežāk tā ir atzī̌anās, ka pilnīga brīvība nav sasniedzama. ${ }^{32}$

30 "Uzdotais jautājums kopsakarā ar tālāk Spriedumā izklāstītiem apsvērumiem liecina, ka lietas izskatīšanas apelācijas instances tiesā robežas noteiktas nepareizi. Lietā nebija risināms jautājums par pārsūdzētā sprieduma motīvu un rezolutatīvās daḷas stāšanos vai nestāšanos spēkā, bet gan par to, kādas sekas rada tas, ka lietas dalībnieks neapstrīd tādus prasības pamatā esošus apstākḷus, kurus tiesa spriedumā atzinusi par nodibinātiem. Kad lieta apelācijas instances tiesā nonāca pirmo reizi, atbildētāja vairs neapstrīdēja prasības pamatā norādīto un pirmās instances tiesas spriedumā atzīto, ka frāzes, kuras prasītājs lūdzis atsaukt, ir ziņas. Pieejams: http://at.gov.lv/lv/tiesu-prakse/judikaturas-nolemumu-arhivs/civillietu-departaments/ hronologiska-seciba?year=2020 [aplūkots 12.02.2021.].

31 Pieejams: http://at.gov.lv/lv/tiesu-prakse/judikaturas-nolemumu-arhivs/civillietu-departaments/hronologiska-seciba?year=2020 [aplūkots 12.02.2021.].

32 Razs Dž. Brīvības morāle. Rīga: Madris, 2001, 379. lpp. 


\section{Kopsavilkums}

1. Pandēmijas un tehnokratizācijas laikā tiesiskā doma turpina savu attīstību. Kritiska un aktīva zinātniskā diskusija notiek. Tas palīdz veidot taisnīgas tiesỉbas un radošu tiesību zinātni. Tiesỉbu zinātnes metodologijā tiek aktualizētas klasiskās zinātniski pētnieciskās metodes.

2. Novērotājs pats ar savu vērtību izpratni ietekmē pētnieciskās pieejas procesu un nevar iegūt neatkarīgu realitātes ainu, līdz ar to zinātniskā atziņa nav iespējami objektīva. Vajadzīga vēl arī atziņas kritika un polemika, pieejamība un pārbaude laikā. Tad to var uzskatīt par tiesību zinātnes atzinu kā tiesību palīgavotu, kas piešḳir tiesībām jēgu un tiesību piemērotājam drošu atbalstu.

3. Tiesību zinātnes radošums un atziṇas zinātniskums tiek pārbaudīts laikā vairākos līmenos:

a) domāšanas un pētniecības darba laika līmenī;

b) radītā darba atziṇu laika lìmenī;

c) atziņu piemērotāja/interpretētāja laika līmenī;

d) atziņu adresāta/novērtētāja laika līmenī.

4. Krīzes situācijas tendence: amatpersonām ir grūtāk respektēt autoritatīvas un fundamentālas tiesību vērtības un tiesību zinātnes atziṇas par brīvību ierobežojumiem. Tas var traucēt izprast likuma patieso standartu un to "piepildìt" ar atbilstošām judikatūras, doktrīnas un tiesnešu īpašās doktrīnas atziņām.

5. Tiesnešu īpašās doktrīnas atziṇas kḷust arvien nozīmīgākas pastāvošo un jaunradāmo tiesību noskaidrošanā un piemērošanā, ir vērtīgs arguments tiesỉbu akta tapšanā. 